\title{
Mathematics Anxiety: A Case Study of Students' Learning Experiences through Cognitive, Environment and Behaviour
}

\author{
Nur Hafizah Musa, Siti Mistima Maat
}

To Link this Article: http://dx.doi.org/10.6007/IJARBSS/v11-i3/8992

DOI:10.6007/IJARBSS/v11-i3/8992

Received: 21 January 2021, Revised: 23 February 2021, Accepted: 04 March 2021

Published Online: 17 March 2021

In-Text Citation: (Musa \& Maat, 2021)

To Cite this Article: Musa, N. H., \& Maat, S. M. (2021). Mathematics Anxiety: A Case Study of Students' Learning Experiences through Cognitive, Environment and Behaviour. International Journal of Academic Research in Business and Social Sciences, 11(3), 932-956.

Copyright: @ 2021 The Author(s)

Published by Human Resource Management Academic Research Society (www.hrmars.com)

This article is published under the Creative Commons Attribution (CC BY 4.0) license. Anyone may reproduce, distribute, translate and create derivative works of this article (for both commercial and non-commercial purposes), subject to full attribution to the original publication and authors. The full terms of this license may be seen

at: http://creativecommons.org/licences/by/4.0/legalcode

\section{Vol. 11, No. 3, 2021, Pg. $932-956$}

Full Terms \& Conditions of access and use can be found at http://hrmars.com/index.php/pages/detail/publication-ethics 


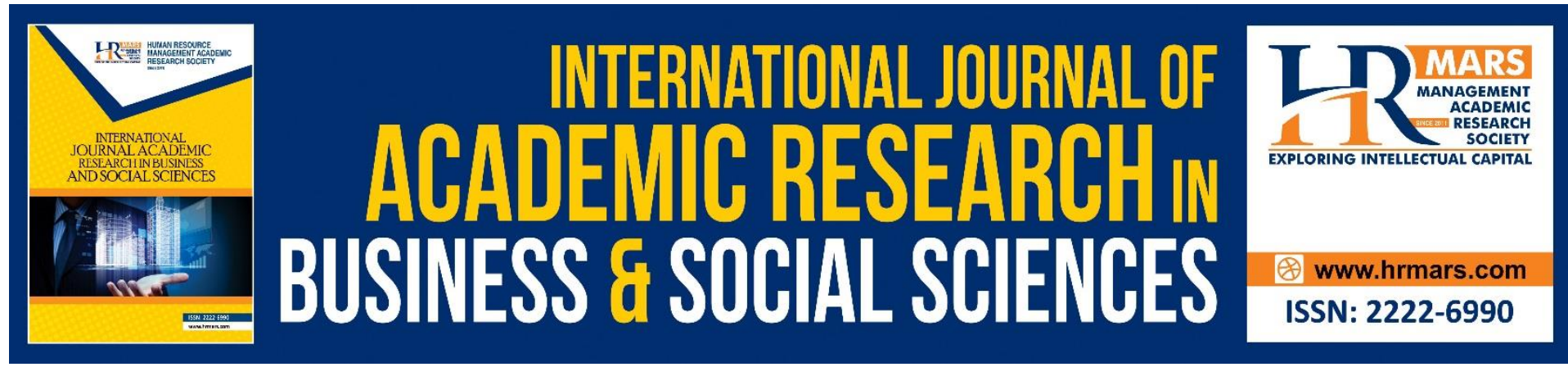

\title{
Mathematics Anxiety: A Case Study of Students' Learning Experiences through Cognitive, Environment and Behaviour
}

\author{
Nur Hafizah Musa, Siti Mistima Maat \\ Faculty of Education, Universiti Kebangsaan Malaysia \\ Email:p96063@siswa.ukm.edu.my, sitimistima@ukm.edu.my
}

\begin{abstract}
Prior research indicated that mathematics anxiety (MA) is considered as significant educational problems since it affected students' emotion, thought and action. Thus, this article aims to explore the issue of MA among secondary school students as viewed through students' learning experiences focusing on three main aspects - cognitive, environment and behaviour. The study also reports on students' mathematics learning anxiety and mathematics assessment anxiety particularly within educational context. A qualitative research approach using case study design was structured in this study. Participants involved 7 highly math-anxious students (aged 16) from a secondary school in Malaysia. The data was collected through semi-structured interview, transcribed and analyzed to establish themes and subthemes. Findings revealed that for anxiety in mathematics learning, stress or pressure and mentality were students main concern for MA whereas for anxiety in mathematics assessment, self-confidence and anxiousness were indicated. As for students' learning experience five subthemes were developed from the findings - (1) self-conflict for cognitive aspect, (2) external influence and (3) content or nature of mathematical knowledge for environmental aspect, (4) the importance of mathematics and (5) strategies in mathematics learning for behavioural aspect. This study also found that MA was experienced by both math high- and low-achieving students. However, for high-achieving students, motivational factor was their main influence towards MA whereas for low-achieving students, poor math competency and self-skills were the major contributors. The article offers in-depth understanding for educators particularly in terms of diagnostic study for MA through student's perspective and they can use this information to identify ways of reducing MA.

Keywords: Mathematics Anxiety (MA), Learning Anxiety, Assessment Anxiety, Cognitive, Environment, Behaviour.
\end{abstract}

\section{Introduction}

Mathematics is one of the branches of knowledge that studies the quantity, structure, space and problem solving that requires skills in calculations and critical thinking (Kusmaryono, Gufron, \& Rusdiantoro, 2020). In general, mathematics plays an important role in every aspect of life, but the main contribution of mathematics is in the field of education. Through the perspective of education globally, mathematics is perceived as one of the most difficult 
subjects to learn due to its complexity and abstract nature (Azizah \& Suhendra, 2020; Haase, Guimarães, \& Wood, 2019). Furthermore, the learning process that is interconnected and requires mastery comprehension from the previous topics causes students to struggle throughout mathematics lesson.

In the context of education, common issues underpinning mathematics learning difficulties are students' lack of conceptual understanding and poor mathematics skills (Salehudin, Hassan, \& Hamid, 2015.). As a result, students tend to be scared, worried and feel less interested to learn mathematics in depth (Nachiappan, 2016; Yahya \& Amir, 2018). However, since mathematics is one of the key elements of success in disciplines ranging from science, technology to economics, excellent qualifications are necessary for students to pursue mathematics at higher level. Therefore, the existing curriculum needs to be reviewed and evaluated constantly to improve the quality of education and produce a world-class mathematics education system.

One of the main challenges for the Ministry of Education Malaysia (MOE) to implement the education transformation plan within the area of mathematics is the deteriorating performance of Malaysian students in mathematics. This concern is based on the report from Trends in International Mathematics and Science Study (TIMSS) in 1999, 2003, 2007, 2011, and 2015 as well as Programme for International Student Assessment (PISA) in 2009, 2012, 2015, and 2018 which shows that Malaysian students' performance in mathematics domain were below average as compared to global average score (Abdullah, Chong, \& Wong, 2017; MOE, 2016; OECD, 2019). The empirical evidence indicates that Malaysian students' level of mathematics competency is lower and far behind the highincome countries especially within Asia. Besides, there is also a report on the declining number of students who choose Science/Technical and Science, Technology, Engineering, and Mathematics (STEM) streams due to students' perception of sciences subject difficulties involving Additional Mathematics, Physics, and Chemistry. Thus, these negative perceptions affect students' interest in mathematics and eventually leads to the emergence of MA.

Other than that, MA is also believed to be indirectly associated with students' emotions, feelings and thoughts. Haase et al. (2019) describe the relation between mathematics and emotions as complex and interconnected where activities involving mathematics can initiate either positive or negative reactions. However, previous studies regarding this issue focused more on the negative side which is related to MA (Deieso \& Fraser, 2019; Gunderson, Park, Maloney, Beilock, \& Levine, 2018; Hill, Mammarella, Devine, Caviola, Passolunghi, \& Szúcs, 2016; Recber, Isiksal, \& Koç, 2018; Rozgonjuk, Kraav, Mikkor, Orav-Puurand, \& Täht, 2020). According to Ashcraft (2002), MA is defined as feeling of tension, apprehension, or fear that interferes with mathematics performance or tasks. Individuals who confronted negative thoughts or feelings have a greater tendency to avoid math-related activities due to their experience in learning (Andrews \& Brown, 2015).

In addition, MA can also lead to serious psychological and psychosomatic problems without proper addressed (Pletzer et al., 2015) since students who experience MA engage in two things at once; dealing with mathematical tasks complexity and overcoming negative feelings or thought (Ramirez, Shaw, \& Maloney, 2018). As a result, students' confidence level and mathematics performance will be affected, subsequently leads to a situation where 
students are no longer interested in learning mathematics (Arslan, 2020). Therefore, MA should be taken seriously as previous evidence suggests that MA has a negative impact on students' achievement at all levels (Ersozlu \& Karakus, 2019), affect students' abilities (Jatisunda et al., 2020) and contributes to students' failure in mathematics (Fong et al., 2017).

Research on MA has a long tradition and since the 1950s, numerous studies have been conducted at the international level. Based on the bibliometric analysis by Ersozlu and Karakus (2019), in the past decades, many researches investigate the factors associated with MA at individual context such as motivation, self-efficacy, self-concept, gender differences and test anxiety. Moreover, the meta-analysis by Namkung, Peng and Lin (2019) involving 131 studies also identified cognitive and environment as the main factors leading to MA. Chang and Beilock (2016) classified these factors into two areas namely individual (cognitive, affective/physiological, motivational) and environmental (social/contextual). This finding is supported by Yahya and Amir (2018) and Garba, Ismail, Osman and Rameli (2020) who found three aspects that affected MA; cognitive, social and individual. Past researches on cognitive aspects mostly focused on self-efficacy and cognitive resource which is working memory (WM) (Beilock \& Maloney, 2015; Ersozlu \& Karakus, 2019; Ramirez et al., 2018). Next, social aspects explore on environmental factors such as parents' mathematical attitudes and concerns (Batchelor, Gilmore, \& Inglis, 2017; Chang \& Beilock, 2016; Maloney, Ramirez, Gunderson, Levine, \& Beilock, 2015), peer influence (Garba et al., 2020) and teaching methods (Mann \& Walshaw, 2019; Sofiatun, Sampoerna, \& El Hakim, 2018). Finally, individual aspects are seen through the student's behaviour such as attitude towards mathematics (Recber et al., 2018) and motivation in learning mathematics (Wang, Lukowski, Hart, Lyons, Thompson, Kovas, \& Petrill, 2015). Findings from these past literatures on MA suggested that it is directly related to cognitive, environment and behaviour. Thus, more comprehensive studies may provide valuable insights into these issues.

Furthermore, although many researchers have examined the issues of MA, most of the studies conducted using quantitative approach (Garba et al., 2019; Namkung et al., 2019) and focused on common factors such as gender, age - level of education, mathematics achievement and performance (Gunderson et al., 2018; Hill et al., 2016). Apart from that, to our knowledge, little attention on MA using qualitative approach has been explored at national level. Most of the quantitative research studies MA related to students' mathematics achievement at school level (Hunt \& Zakaria, 2018; Puteh \& Khalin, 2016; Yahya \& Amir, 2018) or tertiary education (Desa, Saad, Zakaria, \& Zakaria, 2016; Yazid, Azziz, Zakaria, \& Desa, 2016; Zakaria, Azziz, Yazid, \& Saad, 2016). Therefore, there is a need for a more in-depth study to gain better understanding of MA through student's perspective and discover this issue based on students learning experience.

The purpose of this study is to explore the issue of MA among secondary school students who follow the learning system based on Malaysian National Secondary School Standard Curriculum (KSSM). Accordingly, this study focuses on the issue of MA as viewed through students' experiences towards mathematics in the form of cognitive, environment and behaviour.

In summary, the present study is design to answer the following questions: 
- In what way do students experience MA?

- What are the aspects of mathematics learning experience in the form of cognitive, environment and behaviour that contributes to students' MA?

For the next section, literature review related to MA will be further explained, followed by the research methodology process. Then, the findings obtained from this study will be presented and discussed in details. Finally, this paper concludes with implications, limitations and suggestions for further study.

\section{Literature Review \\ Mathematics Anxiety (MA)}

Anxiety refers to an emotional disorder that causes nervousness, fear, worry, panic or apprehension (Jatt, 2019). This situation will indirectly affect how humans act and think. MA occurs when an individual experiences emotional disorders or negative emotion due to situations involving mathematics in learning or daily activities (Namkung et al., 2019). According to Chang and Beilock (2016), math-anxious individuals tend to show psychological symptoms such as tension, negative thinking and avoiding themselves from any mathematical circumstances (Andrews \& Brown, 2015) or physiological symptoms such as sweating, nervous, pale or having high blood pressure (Namkung et al., 2019). Therefore, for math-anxious individuals, solving math-related problems or involving in math-activities are seen as burdens because of an emotional gap (Haase et al., 2019) and there is a tendency for the thought of effects and consequences (Beilock \& Maloney, 2015).

Among the main focus of investigation on MA from the prior studies is the effect of MA on students' performances or achievement in mathematics. Findings from Foley, Herts, Borgonovi, Guerriero, Levine and Beilock (2017), Mutlu (2019), Namkung et al. (2019) and Ramirez et al. (2018) proved that there is a negative correlation between MA and students' performances - a high level of MA leads to poor mathematics achievement. According to Ramirez et al. (2018), this situatioan happened because MA affects students' mathematical abilities or skills. As a result, the student's learning process is disrupted, students feel less motivated (Suren \& Kandemir, 2020), depressed (McDonough \& Ramirez, 2018; Murphy, 2018), less confident (Namkung et al., 2019), reduce student's interest in mathematics and consequently leads to math-avoidance behaviour (Mutlu, 2019). On the other hand, students with high level of self-efficacy (Kahramanoğlu \& Deniz, 2017) will have a positive attitude, tend to be more proficient in mathematics and subsequently enhance their mathematics performance. Situations involving MA, if not properly addressed will lead to the risk of reducing the possibility of students to venture into the field of mathematics at a higher level. This evidence is stated by Dowker, Sarkar and Looi (2016) in which MA affects students' decision involving future studies or the choice of career path. Therefore, identifying the problem of MA especially during the earlier stage of active learning is very important to avoid negative impact in the future and at the same time overcoming MA through the process of recovery and early intervention (Namkung et al., 2019).

Apart from learning, MA is also influenced by assessment. According to Mann and Walshaw (2019), anxiety in assessment is the biggest factor contributing to MA. This is because math-anxious students become very nervous under evaluation and they tend to have a negative perception or expectation towards assessment. This situation coincides with 
Putwain et al. (2015) who defined test anxiety as an individual's tendency to evaluate testing as a form of threat. Andrews and Brown (2015) study of 180 students at the university level also found that student's MA level is higher during assessment than learning. The same findings were also obtained by Arslan (2020) through a study of 337 students, indicating a positive correlation between MA and test anxiety. In fact, according to Arslan (2020), one of the situations that leads to the high level of MA is anxiety during assessment. This is due to the environmental factors such as intense competition and high stress level in community (Koçoğlu \& Kaya, 2016). However, Dowker et al. (2016) argued that although relationship between MA and test anxiety existed, the relationship between other constructs in MA are stronger especially in terms of poor mathematical skills and low mastery level.

\section{Mathematics Learning Experience}

According to Gagné (1985), learning is a process of behavioural changes (outcomes) as a result of the knowledge transmission and skills acquired throughout the process. Experience during the learning process can positively or negatively affect an individual's behaviour depending on the situation involved. Based on Bandura's Social Cognitive Theory (1977, 1986, 1997, 2001), there are three main principles that influence the learning process, namely cognitive, environment and behaviour. All of these elements are interconnected through bidirectional relation. Therefore, according to previous studies, the student's mathematics learning experience is examined through these three aspects; (1) cognitive, (2) environment (social) and (3) behaviour (individual) (Chang \& Beilock, 2016; Garba et al., 2020; Namkung et al. 2019; Suren \& Kandemir, 2020; Yahya \& Amir, 2018). Experience means any occurrence or everything that the students encountered and still remembered throughout the mathematics learning process.

\section{Cognitive}

Cognitive aspect in MA interferes learning abilities that involve individual's perceptions, thoughts or interpretations for future possibilities (Beilock \& Maloney, 2015). This opinion is supported by Haase et al. (2019) who stated that MA disrupts the human's cognitive system and causes the emergence of perceptions through attitudes toward mathematics, math selfconcept and math self-efficacy. This is because low levels of self-efficacy and mathematical skills results in lack of self-confidence, inhibit critical and creative thinking skills and consequently lead to MA (Batchelor et al., 2017; Pletzer et al., 2015; Ramirez et al., 2018). According to Foley et al. (2017), working memory (WM) is an element in the cognitive system that serves as a place to store short-term information and where the process of information manipulation occurs. For math-anxious individuals, the disruption in WM processing triggers limited WM capacity, reduces response levels and information processing which ultimately affects mathematical ability and leads to poor math performance (Namkung et al., 2019). As a result, that person will easily become panic, feel unpleasant and eventually avoid any mathrelated activities (Haase et al., 2019; Ersozlu \& Karakus, 2019).

In addition, based on previous studies, cognitive aspect is also related to self-efficacy. Self-efficacy is defined as belief in one's ability to successfully complete or perform a particular task. Findings suggested that self-efficacy negatively associated with MA (Andrews \& Brown, 2015; Kahramanoğlu \& Deniz, 2017; Rozgonjuk et al., 2020) because students who are less confident in their own math abilities tend to feel nervous or afraid especially in the situations involving tests or evaluations. Self-conflict can also emerges due to the feelings of 
doubt and disbelief in one's own math skills which in turn can affect the learning process. As a result, students who are suffering from this situation will have low levels of self-motivation (Gunderson et al., 2018; Pletzer et al., 2015). This is due to self-efficacy as a major factor that motivates students and determine how much effort or perseverance that they are willing to put in completing math tasks.

\section{Environment}

Next, the environmental aspects mainly associated with influence from external parties such as family members, teachers and friends as well as the content and nature of mathematics knowledge itself. Parents who constantly monitor their children's learning development (Maloney et al., 2015), provide encouragement and motivation (Wang et al., 2015) are believed to help in reducing MA. Even so, Batchelor et al. (2017) found that the negative influence on children's MA stems from the parents' attitudes who have high expectations due to the society and excessive control over their children's academic achievement. However, this situation vary differently for each family according to their background, nurture, characteristic and parents' level of MA (Haase et al., 2019).

As for peer influence, Ditrick (2018) in his study stated that students tend to seek help from their classmates or peers apart from the teacher because they feel more comfortable and less pressure to ask a friend for help in math. In addition, students also utilise guidance and support from peers to improve their performance (Moliner \& Alegre, 2020). This positive effect occurs due to the active and cooperative learning strategies applied in class which enhance student's self-confidence, self-concept and attitude towards mathematics. However, the study of Garba et al. (2019) on highly math-anxious students proved that the main effects of peer influence on MA are through negative aspects such as (1) attitude (overly dominate the class) and (2) conversation (negative words or provocation).

In addition, teachers' attitude and teaching strategies play an important role to influence students' actions and thoughts in math-related activities. This is because effective teaching methods with the use of various strategies will spark students' interests and reinforce their understanding in mathematics concepts (Mann \& Walshaw, 2019). At the same time, teachers also provide supports in terms of emotional (encouragement, confidence, empathy) and instrumental (practical guidance for complex tasks) (Mann \& Walshaw, 2019). However, Cumhur and Tezer (2019) reported opposite findings such that no significant difference existed between student' MA level and teachers' attitude for students at school level. This is because other factors such as emotional and motivation are more dominant in predicting MA. Lastly, Aydin \& Keskin (2017) believed that abstract and complex mathematical concepts as well as students' failure to relate math concepts into real-life situations are the main reasons for MA.

\section{Behaviour}

Behavioural aspects refer to attitudes and strategies in learning mathematics. According to Recber et al. (2018), positive attitudes help to increase students' self-efficacy and in turn reduce the level of MA. Findings from the study of Recber et al. (2018) over 934 school students, showed that attitude is one of the significant construct to determine math achievement because students who have positive math-attitude are always prepared and 
excited toward the learning activities (Suren \& Kandemir, 2020). This situation will indirectly build self-confidence and help students to succeed in mathematics. On the other hand, high math-anxious individuals tend to show negative attitudes because they assume that mathematics is insignificant, have low self-efficacy and have no desire to succeed in mathematics for the future (Maloney et al., 2015). However, anxiety at a moderate level is also necessary especially for highly motivated students to encourage them becoming more eager and diligent in solving challenging math problems. Concurrently, students will always have positive thought and regard math learning as a fun activity (Wang et al., 2015).

Other than that, for some individuals, MA occurs due to the failure of understanding math concepts and insufficient math skills which in turn reducing the level of motivation. If students are overly attached to less flexible problem-solving methods and simple approaches, cognitive systems involving working memory will be disrupted (Morsanyi, Cheallaigh, \& Ackerman, 2019). Thus, students' ability to process information will be affected, particularly for math-anxious students (Namkung et al., 2019). This situation is also more severe in math problems involving abstract and high-order thinking skills (HOTS).

\section{Methodology \\ Research Design}

This qualitative study was structured by using case study design to gain an in-depth understanding of MA according to participants' own experiences. A case study is a holistic exploration of a specific phenomenon arising from particular individuals or groups to obtain a rich explanation (Ghazali \& Sufean, 2018). Therefore, in this research, the case study method was chosen to examine and obtained a detailed interpretation of MA phenomenon for students who follow KSSM syllabus.

\section{Participants and Procedures}

This research consisted of two phases. Phase 1 involved survey and analysis of students' mathematics exam results. Particularly, to identify suitable participants who would fit to be in Phase 2 for the semi-structured interview. This study was conducted in a secondary school in Negeri Sembilan involving 142 Form Four students (age = 16 years old) who follow KSSM syllabus. For Phase 1, all participants completed the MA questionnaire. Then, students' performance in mathematics were analyzed through results from Final Semester Examination and Form Three Assessment (PT3). Based on the findings from Phase 1, a total of seven participants were selected to proceed for Phase 2. These participants were chosen by using purposive sampling method to ensure that they fit the study criteria set by the researcher participant with high level of MA as well as math high- and low-achieving students. The profiles of the selected participants for Phase 2 are as follows: 
Table 3.1: Profile of Participants

\begin{tabular}{llllll}
\hline Category & Gender & $\begin{array}{l}\text { Average } \\
\text { in Mathematics }\end{array}$ & $\begin{array}{l}\text { Mathematics } \\
\text { Achievement }\end{array}$ & $\begin{array}{l}\text { Average score in } \\
\text { MA } \\
\text { questionnaire }\end{array}$ & MA level \\
\hline PR1 & Female & E & Low & 3.96 & High \\
PR2 & Male & E & Low & 4.16 & High \\
PR3 & Female & D & Low & 3.68 & High \\
PR4 & Female & E & Low & 4.32 & High \\
PT1 & Female & A & High & 4.08 & High \\
PT2 & Female & A & High & 4.04 & High \\
PT3 & Male & A & High & 3.84 & High \\
\hline
\end{tabular}

From Table 3.1, in the category section, PR is referring to the math low-achieving participants while PT represent math high-achieving students. Participants are labeled as in Table 1 without using their real names to guarantee and adhere to confidentiality ethics while reporting the findings of the research.

\section{Instruments}

\section{Questionnaire}

The questionnaire adopted from Salwani and Salleh (2001) was used in this study to measure students' MA. Salwani and Salleh (2001) revised a combination of several instruments established from past studies namely Mathematics Anxiety Rating Scale (MARS) by Richardson \& Suinn (1972), Revised Mathematics Anxiety Rating Scale (RMARS) by Plake \& Parker (1982), The Phobus Mathematics Anxiety Inventory by Ferguson (1986) and Kazelskis Anxiety Inventory by Kazelskis (1998). The questionnaire consisted of two sections; demographic (6 items) for Section A and mathematics anxiety, MA (25 items) for Section B. Each item in Section B was measured using a five-point Likert scale ( $1=$ not at all, $5=$ very much). The total score of MA in this questionnaire is 125 which is calculated from the total maximum value of the Likert scale (five for each item). Then, the level of MA of the participants were determined through the average value of the total score as referred from Salwani and Salleh (2001).

\section{Interview}

Next, for Phase 2 of this study, the semi-structured interview protocol was adapted from Croley (2003), Ditrick (2018), Mann (2017) and Murphy (2018). This instrument consisted of 8 open-ended questions and several sub-questions for each. However, since semi-structured interviews were conducted, the questions asked during the interview sessions were flexible and allowed the researcher to spontaneously explore other relevant areas based on the participants' responses. The interviews were approximately between 45 to 90 minutes and recorded with the participants' consents.

\section{Validity and Reliability Instruments}

The MA questionnaire and interview protocol were reviewed by three experts in their respective fields for face and content validity, namely two educators with more than 15 years of experience in language and mathematics as well as a counselor who has served for more than 10 years in the area related to psychology. Then, a pilot study was conducted among 21 
Form Four students in another secondary school at Negeri Sembilan to examine the reliability of the instrument. The result of statistical analysis showed value of Cronbach's Alpha coefficient of 0.801 . Hence, the reliability of this instrument was acceptable as suggested by Hair, Black, Babin, \& Anderson (2013).

\section{Research trustworthiness}

In a qualitative study, the validity and reliability are two substantial criteria to ensure the accuracy and consistency of the data collected (Cohen, Manion, \& Morrison, 2017). Therefore, in order to obtain true results supported by solid evidence, triangulation methods involving document analysis and interviews were conducted by researcher in this study. According to Cohen et al. (2017), triangulation refers to a research technique that uses two or more data collection methods to obtain better understanding and in-depth perspective of the study. Creswell and Poth (2018) also stated that triangulation involves the process of establishing evidences supported by multiple data sources or approaches to ensure the rigorousness of research.

\section{Analysis}

For Phase 1, the data collected were analyzed using Statistical Package for Social Science (SPSS) version 23.0. Descriptive analysis was utilised to determine the total score, the average value of the total score and identify the participants' MA levels. In addition, participants' marks for mathematics in Final Semester Examination and PT3 were analyzed to obtain the average total mark, final grade and determine participants' mathematics achievements.

For Phase 2, all the recorded interviews were transcribed manually into written form or text for data analysis. After that, the transcripts were organized and coded by using ATLAS. Ti version 8.4.3 to establish themes and subthemes that emerged from the data. The findings were then reported, interpreted and discussed according to the research objectives.

\section{Findings}

The findings corresponded to the study were reported based on the research questions. For each research question, several themes and subthemes were identified and grouped by the researcher according to the analysis of the transcripts. These themes and subthemes were supported by statements, responses or feedback from the participants. All of these findings were summarized in the form of table in the next sub-section.

\section{Research Question 1 (RQ1)}

In what way do students experience MA?

For RQ1, two themes, namely (1) anxiety in mathematics learning and (2) anxiety in mathematics assessment were derived by the researcher. The subthemes and issues highlighted for each theme were presented in Table 3.2. 
Table 3.2 : Findings regarding to students' experiences in MA

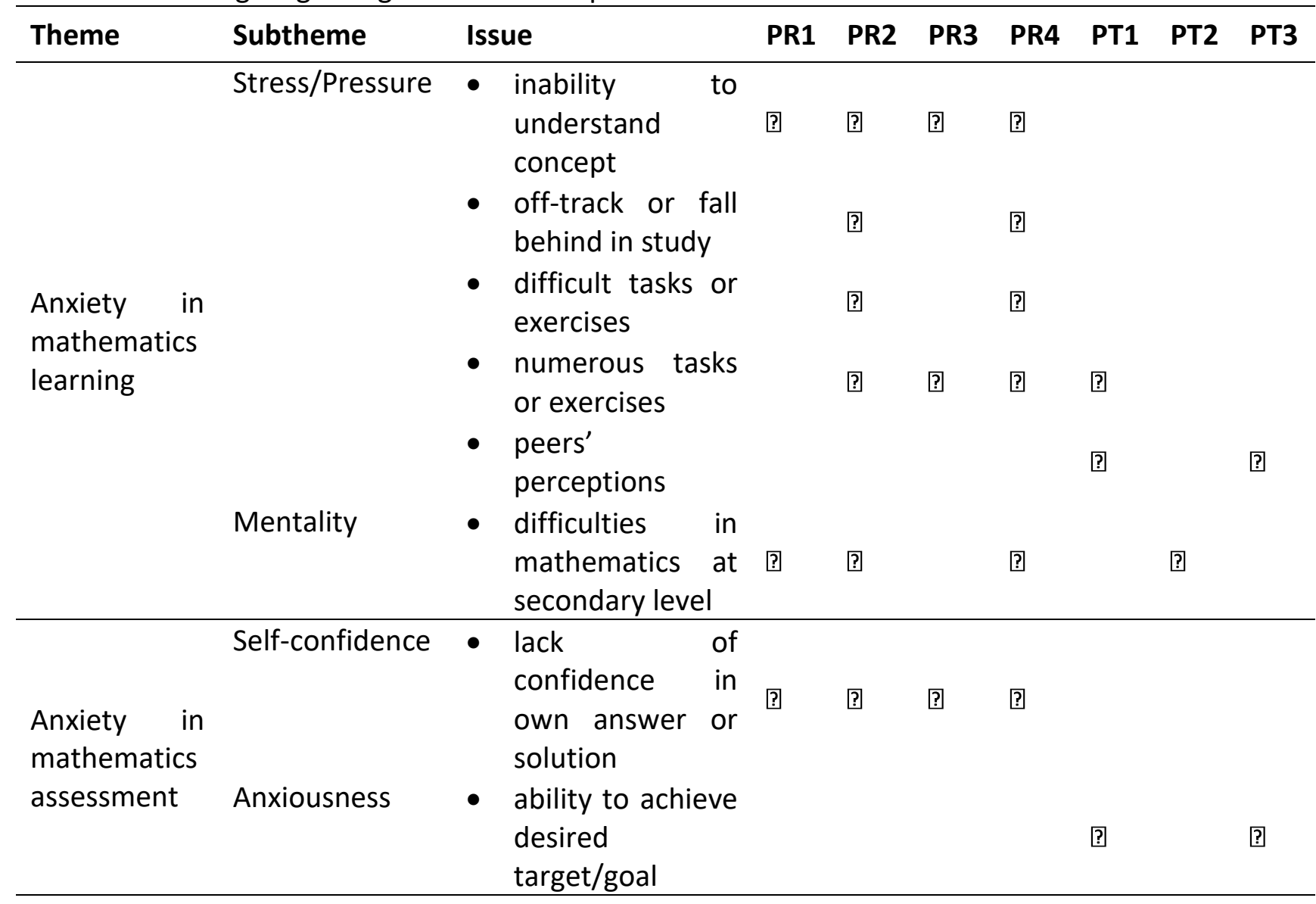

Based on Table 3.2, as viewed through the theme of anxiety in mathematics learning, for subtheme stress or pressure, math low-achieving participants' MA were mainly influenced by their own concerns. For example, these situations happened due to their inabilities to understand complex mathematical concepts, failure to catch up or fall behind in their studies and mathematics tasks or exercises that are too difficult and excessive. Some of the opinions expressed by the participants are as follows:

"First, I feel stressed out because of math class. I will frequently think about what will be taught in the lesson and feel depressed if I do not understand anything because most of the time, I had no idea what the lesson is about. I'm afraid that I will not be able to catch up in class."

"Learning feels more stressful because at least for exam, the topics that will be tested have already been studied. So, I have enough time to prepare and revise. However, during lesson in class, if I failed to understand the topic since the very beginning, then I will feel depressed because I'm at lost throughout the lesson." 
"To be honest, I think in secondary school, there are too much homework and assignments to be done. Some of the questions are too challenging as well, so I feel discourage and burdened."

On the other hand, for math high-achieving participants, the major contribution to the pressure experiences in mathematics learning was due to the external factor such as peers' perceptions. This situation occurred because of the stigmas from their peers who often assume that these excellent students to be know-it-all in mathematics and any problems come easy for them. Participants mentioned their concern as below:

"In class, if the teacher assigned any tasks or exercises to be completed, I feel pressured when my friends asked me how to solve the problem even though I haven't done it yet. Some said that I'm smart, so it's impossible that I don't know how to solve the problems. Sometimes these questions were quite hard, even I myself might have difficulties to come out with the correct answer."

(PT1)

Next, under mentality subtheme, all of the math low-achieving participants and one of the high-achieving participants agreed that mathematics at the secondary level is more complex in nature and requires substantive skills and deep knowledge in order to excel.

"In my opinion, I think that mathematics becomes extremely difficult at higher level. Since I'm not very good in mathematics, the more I learn the harder it is. So, I have negative perception and mind set in this subject especially for the more complicated topics."

As for the second theme, which is anxiety in mathematics assessment, for the selfconfidence subtheme, all of the low-achieving participants experienced this issue. Based on their sharing, the lack of confidence of their own answers and solutions made them feel anxious during examination and interfere their performance.

"During exam, I feel nervous and scared because of the atmosphere, circumstances and mostly the questions asked were quite different from what we have learned in class. Sometimes, I think I can solve the exact same question during lesson but when it comes to exam, my mind suddenly goes blank. I guess maybe because I'm not confident in myself."

On the contrary, for the participants who perform well in mathematics, their main reason for anxiety in mathematics assessment was related to their anxious feeling with their own ability to succeed and achieved desired target in the exam. 
"I am worried that other people get higher marks than me. I wonder if they think that the questions were easy whereas I find it difficult. This situation mostly happened during secondary school. I also compare my marks with friends because I want to determine my ability as compared to others."

"I think during exam, when I got stuck on most of the questions, I feel worried that I will get low marks. I feel more concern on the exam results rather than learning in class."

\section{Research Question 2 (RQ2)}

What are the aspects of mathematics learning experience in the form of cognitive, environment and behaviour that contributes to students' MA?

For RQ2, three themes, namely (1) experience through cognitive aspects, (2) experience through environmental aspects and (3) experience through behavioural aspects were identified by the researcher. All subthemes and issues related to each theme were summarized in Table 3.3. 
Table 3.3 : Findings regarding to learning experiences in mathematics

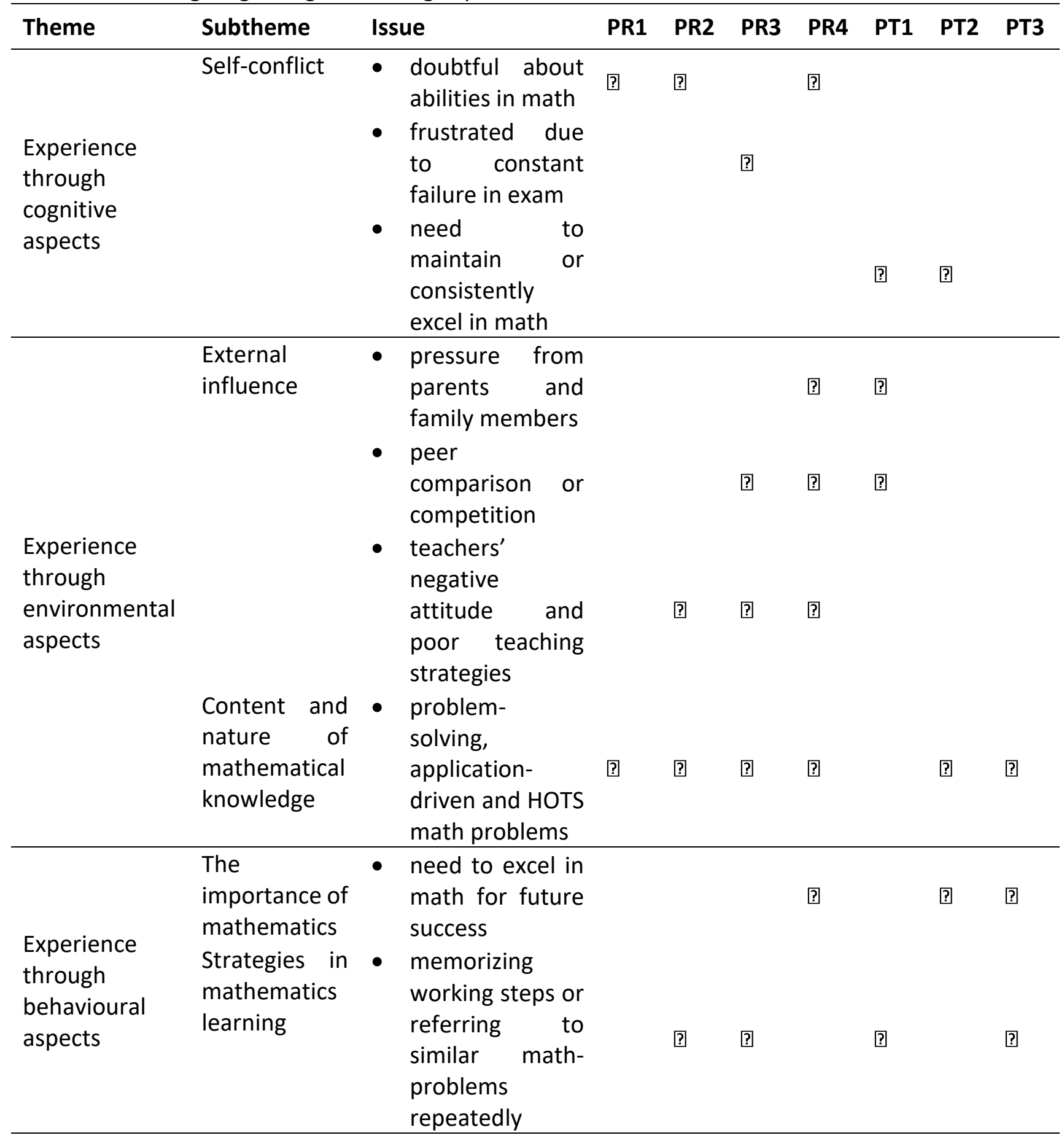

Based on Table 3.3, for the first theme involving experience through cognitive aspects, math low-achieving participants encountered self-conflict due to their uncertainties and feeling of doubtful with their own abilities in mathematics. Besides, inconsistent scores and experience in math exam failure also led to the higher level of MA.

"Learning math in secondary school is indeed affected my mind and perception towards mathematics as a whole. I'm always wondering why I need to learn math and my mind is always filled with negative thought." 
"I have experience of repeatedly failed in math exams. When it happened, I felt disappointed and wanted to give up on math."

As for math high-achieving participants, self-conflict occurred due to their ability to maintain their best performances and consistently excel in mathematics.

"During exam, I always target for the best result or highest ranking. If I do not reach my target, I will feel very frustrated and afraid of losing my momentum. If that really happened, then I will work on something to improve my score."

Next, for the second theme - experience through the environmental aspects, some the issues related to the external influence as stated by the participants were pressure from parents and family members, peer comparison or competition, teachers' negative attitude and poor teaching strategies.

"I felt down when my parents compare me with other siblings in terms of academic performance."

"A lot of my friends are very good in math during secondary school. For this reason, somehow, I become inferior. In the final semester exam, other people always scored well in math, but I didn't get good marks. I felt sad because the marks are not what I expected."

"In terms of feelings, since I am an emotional person, then teachers' negative attitudes have major impact on my math learning."

"I personally think that teacher really influence my attitude and interest towards learning. If I couldn't keep pace with the teacher's lesson and feel sleepy, then it means that the teaching style is monotonous and hard to understand."

As for the content and nature of mathematical knowledge, the type of problemsolving questions with the use of application and HOTS were the main reasons for students learning difficulties in math. In fact, this situation happened to both math high- and lowachieving participants.

"If the question involves problem-solving and contains wordy math problem, then I found it more challenging to be solved because I have to look for the real issue and choose formula appropriately." 
"I think HOTS questions are generally more difficult because they are quite different from what we learned in class. Most of the time, I have no idea what the question is about."

Finally, for the third theme - experience through the behavioural aspects, the importance of mathematics for the future in terms of career opportunities and pursue studies effected participants' opinions towards math. As a result, this situation makes them to be more diligent and enthusiastic in math learning but at the same time feel worried for the possibility of negative consequences.

"As the exams are coming, I become more diligent in my studies and I spend most of the time doing revisions and exercises. That is because I need good grade to get a decent job for the future."

For subtheme involving strategies in mathematics learning, both excellent and lowachieving participants agreed that they often used the method of memorizing the working steps and referring to similar problems repeatedly when dealing with math questions. This in turn, affected students' math ability and skills in the long-term because they tend to use the same strategies for similar cases.

"I am more into memorization for solving math problems. For example, during exam, I will remember every working step from similar problems and write down each of the step to solve the question."

\section{Discussion \\ MA Experienced by Students}

In this study, the findings suggest that MA experienced by students is based on two different situations, namely anxiety in mathematics learning and mathematics assessment. As for the anxiety in learning, in particular, students encounter stress due to mathematical concepts or content that are too complicated. Hence, this makes students to experience difficulties in understanding the whole topic, solving complex math-problem and consequently being left behind in class. This problem is more prominent for math low-achieving students due to their limited mathematical competencies and skills. This evidence is in line with Murphy (2018) and McDonough and Ramirez (2018) who found that stress experienced in the classroom leads to the emergence of MA. Accordingly, these students who are in a stressful situation due to mathematics learning are more likely to forget the knowledge they learn as a result of self-concept disruption.

In addition, most students agree that excessive amount of homework assigned by teachers also lead to the onset of stress in mathematics learning. This is because students feel burdened with the assignments given, particularly for challenging math problems. This finding is supported by Murphy (2018) who found that students feel stressed and frustrated while doing math exercises due to difficulty or failure to understand the task. However, students, especially those who excelled, also expressed that regular and reasonable amount 
of exercises are very important to improve their math ability. In fact, this continuous math practice has proven to be helpful in overcoming MA (Cumhur \& Terzer, 2019).

For math high-achieving students, the main reason for stress in mathematics learning is peers' perceptions. This situation is believed to occur due to stigma from peers on the exceptional abilities of these outstanding students and their capabilities to solve any mathrelated problems. Although this situation is not considered as critical, unconsciously other's perception can negatively impact students. This is also reported by Furner (2017) through the study of gifted students who found that social stigma from peers will affect students' emotions and indirectly prevent students from achieving their true self-potential.

Next, the mentality of students who think that mathematics is becoming more difficult to learn at secondary school also leads to MA. This negative thinking may occur due to the complexity and diversity of mathematics syllabus at secondary school. Besides, there are a lot of new concepts that are more challenging, unfamiliar and require good mathematical skills. According to Deieso and Fraser (2019) and Mann (2017), school transition from the lower to the higher level is one of the main factors influencing MA. This is because the learning process become unenjoyable, boring and difficult to comprehend for more complex math knowledge.

As for anxiety in mathematics assessment, the findings indicate that math lowachieving students feeling of doubtful and lack of self-confidence while answering math questions contibute to MA. This finding is in line with the study of Akbayır (2019) and Suharto and Widada (2019) who found that anxiety in exams arises due to the feeling of insecurity and this prevents students from thinking clearly under evaluation circumstances. According to Mann and Walshaw (2019), this situation is more critical for math-anxious students because they are more likely to have negative perceptions on assessment. However, Dowker et al. (2016) argued that other constructs such as math competency and skill are more dominant than test anxiety.

Instead, for high performance students, anxiety in assessment is triggered due to the concerns about examination results and ability to achieve desired targets. This situation may occur because students who excel in academic, especially within Asia are more likely to set high goals in education and undergone rigorous evaluation standard due to social stigma and educational environment (Choi-Koh \& Ryoo, 2019). This finding is also supported by Koçoğlu and Kaya (2016) who stated that environmental factors such as intense competition and external pressure lead to high levels of MA.

\section{Mathematics Learning Experience Cognitive aspect}

For math low-achieving students, experience through cognitive aspects is believed to stem from internal conflict. Feelings of doubt about one's ability and frustration at often failing exams make students think negatively. As a result, the students' level of self-efficacy is declining and this situation if continued will lead to an increase of MA. This is in line with the findings from Andrews and Brown (2015), Kahramanoğlu and Deniz (2017) and Rozgonjuk et al. (2020). Besides, this situation occurs because anyone who think that they are weak in mathematics will have negative attitude, less motivated to complete math tasks and 
consequently avoid any activities involving mathematics (Ersozlu \& Karakus 2019; Haase et al., 2019).

On the other hand, for math high-achieving students, self-conflict arises due to the need of maintaining excellent performance. Feelings of frustration and dissatisfaction due to poor math performances will elicit negative thoughts on their own abilities. As a result, students feel disturbed and if positive action is not taken, students' motivation will decrease and consequently affect their learning process (Gunderson et al., 2018). This is also agreed by Maloney et al. (2015) who stated that negative perceptions make students feel less motivated and influence students' efforts or determination in math learning. If this happens, the learning process will be less stimulating and indirectly leads to MA.

\section{Environmental aspect}

Experience through the environmental aspects occurs due to the influence of external parties. Both high- and low-achieving students claims that pressure from parents, family members as well as peers competition also contributes to MA. Parents' act of comparing their children's achievements is one of the reasons why students feel burdened and worried if they fail to get good results. These findings coincide with the study of Batchelor et al. (2017) who stated that parents' attitudes such as high expectations and overcontrol towards children's academic performance negatively effects MA. However, parents' roles are also very crucial in children's math learning because parents who constantly monitor and provide support can help to reduce MA (Maloney et al., 2015).

In terms of peer perspective, competitive factors involving performance and exam results influence students' math self-confidence and make students feel inferior as compared to others. This is because according Ditrick (2018), peers are among the individuals believed to be important in academic related matters. Therefore, this belief can either positively influence students through guidance to improve performance or negatively through provocative attitude or words. However, Garba et al. (2020) countered that peer competition is essential to reduce MA because peer success will inspires and motivates students to be more diligent in math.

In addition, according to math low-achieving students, teachers with negative attitude and less effective teaching strategies influence students' interest in mathematics. Teachers who are strict, forceful, boring and restricted to certain or ineffective ways of teaching make students become less attached to math learning. This is because teacher plays an enormous role to create an effective learning environment emotionally or practically (Mann \& Walshaw, 2019). These findings are in parallel with the results from Wang et al. (2015) and Chang and Beilock (2016). Despite, Cumhur and Tezer (2019) found evidence of other more dominant factors such as feeling stressful and fear of success in predicting MA.

As for the environmental aspects involving the content and nature of mathematics knowledge, majority of the students find it difficult to grasp math problems that are sentence-based, involve applications and require HOTS. This situation occurs due to students' inability to identify sufficient clues and choose appropriate method of solving the problems. The students' failure to make connection between abstract math concepts to real- 
life situation (Aydin \& Keskin, 2017), poor math-reasoning skills as well as low math problemsolving ability also affected MA (Suharto \& Widada, 2019). Therefore, according to Ramirez et al. (2018), in order to overcome this problem, exposure to more flexible mathematics strategies must be instilled throughout learning process.

\section{Behavioural Aspect}

As for behavioural aspect, students' awareness toward the importance of mathematics for the future indirectly contributes to students' MA. This is because students believe that success in mathematics will ensure life security either in terms of employment or opportunity to further studies at a higher level. Therefore, students deem to be diligent, engage in depth learning and perform well in mathematics. According to Recber et al. (2018), this positive attitude or behaviour is effective in reducing MA. However, the findings in this study showed contradiction such that positive attitude and motivation to succeed exhibit higher level of MA because within the context of this study, students experience more dominant psychological disorders such as depression and anxiety about self-performance. This is also supported by Cumhur \& Tezer (2019), who found that fear of success in mathematics for the sake of the future is a major factor in determining students' MA.

Next, in terms of the strategies used for math learning, students from both high- and low-level of achievements stated that they frequently used the method of memorization and referrring to similar-typed questions to solve math problems. Students argue that these methods assure them to determine the correct formula and apply simple techniques for solutions. In addition, for limited time context like in exam, students feel more confident with their working if they apply thsese strategies. These findings are in line with previous studies because MA limits students' skills for in-depth reasoning and reflection (Primi, Donati, Chiesi, \& Morsanyi, 2017) as well as reducing their working memory capacity (Mutlu, 2019). Moreover, math-anxious students are more likely to rely on heuristic method but there is a possibility that such method may fail to achieve optimal solutions (Morsanyi et al., 2019). However, for students with high competency in mathematics, the method of memorisation does not inhibit them from applying flexible methods because they believe that challenging math problems will indirectly require deep thinking and enable maximum use of reasoning or conceptual skills.

\section{Limitations, Implications and Recommendations for Future Studies}

This present study explores the issue of MA specifically through students' perspectives. Therefore, these findings might be limited to their experience. To gain an even broader understanding, teachers and parents perspectives should also be investigated. This is because $M A$ is not only related to the individuals but also interactions with other people. Findings from this study are expected to provide guidance and in-depth understanding for teachers or educators so that they can focus on specific or dominant issues depending on students' background. A learning environment that is able to stimulate students' interest in mathematics, especially for abstract and complex topics as well as effective teaching methods through 21st century learning-based pedagogy should be emphasized in today's educational framework. According to Suren \& Kandemir (2020), this situation allows students to always think positively, become more confident and feel motivated to learn. Besides, teachers need to create a learning environment that will not only encourage students engagement and motivates students to learn but also eliminate any occasions that can lead to MA. Parents and 
family members on the other hand should also work together to help students overcoming their MA by giving continuous supports and assisting them through any obstacle in learning mathematics. Parents involvement can affect students' emotional aspect and indirectly enhance their potential to perform well in math-related task and consequently reduce their MA. Furthermore, an active collaboration between teachers, school administrators and parents can also establish a medium to monitor students' progress and provide supports from all areas.

On a separate note, the context of this study is also limited to the diagnostic aspect for MA experienced by students. Therefore, further studies focusing on intervention and recovery process can be implemented to identify the best solution that works on different type of students according to their skills and academic level. Moreover this study only involved a small group of students within limited time period. Therefore, the findings are more relatable for individuals with a similar educational background. For further studies, longitudinal research to examine the development of MA through different levels of education particularly during the transition process should be conducted for improvement.

In particular, based on the findings obtained, all three aspects of cognitive, environmental and behaviour contribute to students' MA. For low-achieving students, cognitively, self-conflict that mainly arouse from the feeling of doubtful about one's own abilities in mathematics cause a detrimental effect on students' performance in mathematics. This situation was triggered by negative mathematics experiences such as increase difficulty of mathematics syllabus and complexity of mathematics concept. In order to overcome this problem, various learning strategies such as collaborative learning, presentation and small group mentoring can be implement to help less able students overcoming their anxiety. It will help students to build self-confidence and become more engaged in the learning process. On the other hand, for math high-achieving students, MA experienced through cognitive aspect was indicated by ability to maintain and excel in mathematics which also affected the way they behave towards achieving their targets. Thus, alternative assessment such as mathrelated projects, investigations, portfolios or exhibitions should be introduced to provide different options and expose students with mathematics at a more complex level. Besides, it can avoid math-high achieving students from becoming exam-oriented and be more openminded.

As for environmental aspects, findings suggested that teachers were the prime factor that influence low-performing students' anxiety in mathematics. Their attitudes and strategies in teaching mathematics - harsh or poor teaching style and little motivational support were the main reasons for increased in MA. This study also revealed that, the content and nature of mathematical knowledge itself that requires math-skills involving application and HOTS problem solving highly affected the development of MA. This situation is particularly apparent among students who experience difficulties with mathematics. One of the way to address this issue is by emphasising on mathematical conceptual knowledge and exposure to math-problem focusing on the application of knowledge and skills in real-life context. Teachers need to ensure that in a mathematics classroom, conceptual understanding is given prioritize rather than purely rely on procedural understanding. 
Finally, math-anxious students behaviour towards mathematics task in this study showed that inadequate strategies such as constantly memorising working steps contributes to the onset of MA. Consequently, this behaviour leads to skill and performance deficits in mathematics. Therefore, teachers play a vital role in guiding students the effective ways to deal with strategies when solving math-problems rather than memorising working steps.

\section{Conclusion}

In general, this study provides evidence that MA is experienced by students within both learning and assessment context. The main reason for anxiety in learning as stated by most of the participants was due to the content and math concepts that are increasingly difficult at advance level. Meanwhile, the anxiety suffered during assessment is due to the lack of confidence and anxious feeling while answering questions within a set period of time. Based on students' learning experience as mention by the participants, all three aspects of cognitive, environmental and behaviour contribute to students' MA. In addition, this study also found that MA is not only encountered by math low-achieving students, but also excellent students. This is also confirmed by the study of Furner (2017), Yazgan-Sag and Argun (2020) and Zhang, Zhao and Kong (2019). However, the factors that influence the anxiety of high-performing students are mainly due to motivational factors such as the need to achieve desired targets and maintain excellence in mathematics for a secure future. On the other hand, for low-performing students, MA arises due to limited math competency and self-skills that lead to negative perceptions on mathematics.

\section{Acknowledgement}

This research was funded by the Faulty of Education, Universiti Kebangsaan Malaysia grant GG-2020-016.

\section{References}

Abdullah, A. H., Chong, S. Y., \& Wong, J. T. (2017). Pencapaian matematik TIMSS 1999, 2003, 2007, 2011 dan 2015: di mana kedudukan Malaysia dalam kalangan negara Asia Tenggara? Malaysian Journal of Higher Order Thinking Skills in Education, 54-108.

Akbayır, K. (2019). An investigation about high school students' mathematics anxiety level according to gender. Journal of Education and Training Studies, 7(7), 62-70.

Andrews, A., \& Brown, J. (2015). The effects of math anxiety. Education, 135(3), 362-370.

Arslan, Ç. (2020). Examining the relationship between 5-8th grade students' test anxiety and mathematics anxiety. Acta Didactica Napocensia, 13(1), 127-137.

Ashcraft, M. H. (2002). Math anxiety: personal, educational, and cognitive consequences. Current Directions in Psychological Science, 11(5), 181-185.

Aydın, M., \& Keskin, I. (2017). The investigation of 8th graders ' mathematical anxiety levels in terms of some variables. Kastamonu Education Journal, 25(5), 1801-1818.

Azizah, S. N., \& Suhendra. (2020). Mathematics anxiety of senior high school students based on extrovert and introvert personality types. Journal of Physics Conference Series, 1521(3).

Bandura, A. (1977). Self-efficacy: toward a unifying theory of behavioral change. Psychological Review, 84(2), 191-215.

Bandura, A. (1986). Social foundations of thought and action: A social cognitive theory. Englewood Cliffs, NJ: Prentice-Hall.

Bandura, A. (1997). Self-efficacy: The exercise of control. New York: W.H. Freeman. 
Bandura, A. (2001). Social cognitive theory: an agentic perspective. Annual Review of Psychology, 52(1), 1-26.

Batchelor, S., Gilmore, C., \& Inglis, M. (2017). Parents' and children's mathematics anxiety. In. $\mathrm{U}$. Xolocotzin Eligio (Ed.), Understanding emotions in mathematical thinking and learning (pp. 315-336). San Diego: Academic.

Beilock, S. L., \& Maloney, E. A. (2015). Math anxiety: A factor in math achievement not to be ignored. Policy Insights from the Behavioral and Brain Sciences, 2(1), 4-12.

Chang, H., \& Beilock, S. L. (2016). The math anxiety-math performance link and its relation to individual and environmental factors: A review of current behavioral and psychophysiological research. Current Opinion in Behavioral Sciences, 10, 33-38.

Choi-Koh, S. S., \& Ryoo, B. G. (2019). Differences of math anxiety groups based on two measurements, MASS and EEG. Educational Psychology, 39(5), 659-677.

Cohen, L., Manion, L., \& Morrison, K. (2017). Research Methods in Education ( ${ }^{\text {th }}$ Ed.). USA: Routledge.

Creswell, J. W., \& Poth, C. N. (2018). Qualitative inquiry \& research design: Choosing among five approaches (4th Ed.). Thousand Oaks, CA: SAGE Publications, Inc.

Croley, M. B. (2003). Factors that produce and reduce mathematics anxiety as perceived by seventh-grade females: A qualitative study. [Doctor of Education Dissertation Thesis, Montclair State University].

Cumhur, M., \& Tezer, M. (2019). Anxiety about mathematics among university students: a multi-dimensional study in the 21st century. Cypriot Journal of Educational Sciences, 14(2), 222-231.

Deieso, D., \& Fraser, B.J. (2019). Learning environment, attitudes and anxiety across the transition from primary to secondary school mathematics. Learning Environments Research, 22(1), 133-152.

Desa, A. M., Saad, S. A., Zakaria, S. A., \& Zakaria, M. H. (2016). Exploring mathematics anxiety among first year business students: UniMAP experience. AIP Conference Proceedings, $1775,1$.

Ditrick, L. K. (2018). I can't do math! Reflections on mathematics anxiety in secondary schools. [Dissertation Thesis (Honors), Kent State University].

Dowker, A., Sarkar, A., \& Looi, C. Y. (2016). Mathematics anxiety: what have we learned in 60 years? Frontiers in Psychology, 7(508).

Ersozlu, Z., \& Karakus, M. (2019). Mathematics anxiety: mapping the literature by bibliometric analysis. EURASIA Journal of Mathematics, Science and Technology Education, 15(2), 1673.

Ferguson, R. D. (1986). Abstraction anxiety: a factor of mathematics anxiety. Journal for Research in Mathematics Education, 17(2), 145-150.

Foley, A. E., Herts, J. B., Borgonovi, F., Guerriero, S., Levine, S. C., \& Beilock, S. L. (2017). The math anxiety-performance link: A global phenomenon. Current Directions in Psychological Science, 26(1), 52-58.

Fong, C. J., Davis, C. W., Kim, Y., Kim, Y. W., Marriott, L., \& Kim, S. (2017). Psychosocial factors and community college student success. Review of Educational Research 87(2), 388424.

Furner, J. M. (2017). Helping all students become Einstein's using bibliotherapy when teaching mathematics to prepare students for a STEM world. Pedagogical Research, 2(1), 1.

Gagné, R. M. (1985). Conditions of learning and theory of instruction. New York: Holt, Rinehart and Winston. 
Garba, A., Ismail, N., Osman, S., \& Rameli, M. R. M. (2020). Exploring peer effect on mathematics anxiety among secondary school students of Sokoto State, Nigeria through photovoice approach. Eurasia Journal of Mathematics, Science and Technology Education, 16(2).

Darusalam, G., \& Hussin, S. (2018). Metodologi penyelidikan dalam pendidikan (Ed. Ke-2). Kuala Lumpur: Penerbit Universiti Malaya.

Gunderson, E. A., Park, D., Maloney, E. A., Beilock, S. L., \& Levine, S. C. (2018). Reciprocal relations among motivational frameworks, math anxiety, and math achievement in early elementary school. Journal of Cognition and Development, 19(1), 21-46.

Haase, V. G., Guimarães, A.P.L. \& Wood, G. (2019). Mathematics and emotions: the case of math anxiety. In. International Handbook of Mathematical Learning Difficulties (pp. 469-503). Springer: Cham.

Hair, J. F., Black, W. C., Babin, B. J., \& Anderson, R. E. (2013). Multivariate data analysis (7 Pearson new international Ed.). Harlow: Pearson.

Hill, F., Mammarella, I. C., Devine, A., Caviola, S., Passolunghi, M. C., \& Szűcs, D. (2016). Maths anxiety in primary and secondary school students: gender differences, developmental changes and anxiety specificity. Learning and Individual Differences, 48, 45-53.

Hunt, W. C., \& Zakaria, E. (2018). Hubungan antara kebimbingan matematik dan pencapaian matematik murid sekolah rendah. Prosiding Seminar Kebangsaan Majlis Dekan Pendidikan Universiti Awam. 2011, 7-8.

Jatisunda, M. G., Kania, N., Suciawati, V., \& Nahdi, D. S. (2020). Student mathematical anxiety: investigation on problem based learning. Journal of Physics: Conference Series, 1613(1).

Jatt, S. S. (2019). Relationship of mathematics anxiety with high school students' achievement. Journal of Science Education, 1(1).

Kahramanoğlu, R., \& Deniz, T. (2017). An investigation of the relationship between middle school students' metacognitive skills, mathematics self-efficacy, and mathematics achievement. Inonu University Journal of the Faculty of Education, 18(3), 189-200.

Kazelskis, R. (1998). Some dimensions of mathematics anxiety: A factor analysis across instruments. Educational and Psychological Measurement, 58(4), 623-633.

Koçoğlu, E., \& Kaya, F. (2016). Metaphorical realizations the exam concept of 8th students towards of middle school in Turkey. Electronic Turkish Studies, 11(19), 579-600.

Kusmaryono, I., Gufron, A. M., \& Rusdiantoro, A. (2020). Effectiveness of scaffolding strategies in learning against decrease in mathematics anxiety level. NUMERICAL: Jurnal Matematika Dan Pendidikan Matematika, 4(1), 13-22.

Maloney, E. A., Ramirez, G., Gunderson, E. A., Levine, S. C., \& Beilock, S. L. (2015). Intergenerational effects of parents' math anxiety on children's math achievement and anxiety. Psychological Science, 26(9), 1480-1488.

Mann, L. C. (2017). Unpacking mathematics anxiety in year 9 students. [Master of Education Thesis, Massey University].

Mann, L. C., \& Walshaw, M. (2019). Mathematics anxiety in secondary school female students: issues, influences and implications. New Zealand Journal of Educational Studies, 54(1), 101-120.

McDonough, I. M., \& Ramirez, G. (2018). Individual differences in math anxiety and math selfconcept promote forgetting in a directed forgetting paradigm. Learning and Individual Differences, 64, 33-42.

Ministry of Education Malaysia (MOE). (2016). Laporan TIMSS 2015-Trends in International Mathematics and Science Study. Putrajaya: Malaysian National Library. 
Moliner, L., \& Alegre, F. (2020). Peer tutoring effects on students' mathematics anxiety: a middle school experience. Frontiers in Psychology, 11, 1610.

Morsanyi, K., Cheallaigh, N. N., \& Ackerman, R. (2019). Mathematics anxiety and metacognitive processes: proposal for a new line of inquiry. Psihologijske Teme, 28(1), 147-169.

Murphy, D. (2018). A phenomenological study of college students in developmental mathematics classes experiences with mathematics and computer anxiety. [Doctor of Education Dissertation Thesis, Liberty University].

Mutlu, Y. (2019). Math anxiety in students with and without math learning difficulties. International Electronic Journal of Elementary Education, 11(5), 471-475.

Nachiappan, S., Rengasamy, K., Maniam, V., Ganaprakasam, C., \& Zulkafaly, M. F. (2016). Analisis pengajaran guru dalam mata pelajaran matematik ke arah aplikasi kognisi dalam kurikulum standard sekolah rendah melalui kaedah hermeneutik. EDUCATUMJournal of Social Science, 2(1), 31-41.

Namkung, J. M., Peng, P., \& Lin, X. (2019). The relation between mathematics anxiety and mathematics performance among school-aged students: A meta-analysis. Review of Educational Research, 89(3), 459-496.

OECD. (2019). PISA 2018 Results: Combined Executive Summaries Volume I, II \& III. Paris, Perancis: OECD Publishing.

Plake, B. S., \& Parker, C. S. (1982). The development and validation of a revised version of the mathematics anxiety rating scale. Educational and Psychological Measurement, 42, 551-557.

Pletzer, B., Kronbichler, M., Nuerk, H.-C., \& Kerschbaum, H. H. (2015). Mathematics anxiety reduces default mode network deactivation in response to numerical tasks. Frontiers in Human Neuroscience, 9, 202.

Primi, C., Donati, M. A., Chiesi, F., \& Morsanyi, K. (2017). Are there gender differences in cognitive reflection? Invariance and differences related to mathematics. Thinking \& Reasoning, 24(2), 258-279.

Puteh, M., \& Khalin, S. Z. (2016). Mathematics anxiety and its relationship with the achievement of secondary students in Malaysia. International Journal of Social Science and Humanity, 6(2), 119.

Putwain, D. W., Daly, A. L., Chamberlain, S., \& Sadreddini, S. (2015). Academically buoyant students are less anxious about and perform better in high-stakes examinations. British Journal of Educational Psychology, 85(3), 247-263.

Ramirez, G., Shaw, S. T., \& Maloney, E. A. (2018). Math anxiety: past research, promising interventions, and a new interpretation framework. Educational Psychologist, 53(3), 145-164.

Recber, S., Isiksal, M., \& Koç, Y. (2018). Investigating self-efficacy, anxiety, attitudes and mathematics achievement regarding gender and school type. Anales de Psicología/Annals of Psychology, 34(1), 41-51.

Richardson, F. C., \& Suinn, R. M. (1972). The mathematics anxiety rating scale: psychometric data. Journal of Counseling Psychology, 19(6), 551-554.

Rozgonjuk, D., Kraav, T., Mikkor, K., Orav-Puurand, K., \& Täht, K. (2020). Mathematics anxiety among STEM and social sciences students: the roles of mathematics self-efficacy, and deep and surface approach to learning. International Journal of STEM Education, 7(1), $1-11$. 
Salehudin, N. N., Hassan, N. H., \& Hamid, N. A. A. (2015). Matematik dan kemahiran abad ke21: perspektif pelajar. Jurnal Pendidikan Matematik, 3(1), 24-36.

Salwani, T., \& Salleh, A. (2001). Perkaitan antara kerisauan matematik dengan pencapaiannya di sebuah institusi pengajian teknikal. [Unpublished Master Thesis]. Fakulti Pendidikan, Universiti Kebangsaan Malaysia.

Sofiatun, S., Sampoerna, P. D., \& El Hakim, L. (2018). The effect of scaffolding techniques on the ability of student's reasoning ability and mathematics anxiety reviewed from gender. Unnes Journal of Mathematics Education, 7(1), 63-71.

Suharto, S., \& Widada, W. (2019). The students' anxiety in facing the mathematical national exams. 3rd Asian Education Symposium (AES 2018). Atlantis Press 253.

Suren, N., \& Kandemir, M. A. (2020). The effects of mathematics anxiety and motivation on students' mathematics achievement. International Journal of Education in Mathematics, Science and Technology, 8(3), 190-218.

Wang, Z., Lukowski, S. L., Hart, S. A., Lyons, I. M., Thompson, L. A., Kovas, Y., \& Petrill, S. A. (2015). Is math anxiety always bad for math learning? The role of math motivation. Psychological science, 26(12), 1863-1876.

Yahya, S. Z., \& Amir, R. (2018). Kebimbangan matematik dan pencapaian matematik tambahan. Journal of Nusantara Studies (JONUS), 3(2), 124-133.

Yazgan-Sag, G., \& Argun, Z. (2020). Self-reflections of gifted students in the context of mathematical problem solving. Malaysian Online Journal of Educational Sciences, 8(2), 14-27.

Yazid, N. M., Azziz, N. H. A., Zakaria, S. A., \& Desa, A. M. (2016). Anxiety level on mathematics among engineering technology undergraduates in UniMAP. AIP Conference Proceedings, 1775, 1.

Zakaria, M. H., Azziz, N. H. A., Yazid, N. M., \& Saad, S. A. (2016). The anxiety level versus performance in mathematics for engineering undergraduates in UniMAP. AIP Conference Proceedings, 1775, 1.

Zhang, J., Zhao, N., \& Kong, Q. P. (2019). The relationship between math anxiety and math performance: a meta-analytic investigation. Frontiers in Psychology, 10. 